\title{
Pulmonary function among pulp and paper workers in Berlin, New Hampshire
}

\author{
P K HENNEBERGER, ' ELLEN A EISEN, ' B G FERRIS JR ${ }^{2}$
}

From the Occupational Health Program ${ }^{\prime}$ and Respiratory Epidemiology Program, ${ }^{2}$ Harvard School of Public Health, Boston, Massachusetts 02115, USA

ABSTRACT Pulmonary function was studied among pulp and paper workers from a production facility in New Hampshire. Subjects were first tested in the 1960 s and then surveyed at regular intervals up to 1985. The current study examined results for the 339 subjects who participated in at least one of the two most recent follow up surveys in 1979 and 1985 . For the 171 subjects who were tested in both surveys, the pulmonary function values were higher and the effect of pulp mill work was diminished compared with the findings for the 168 subjects who were tested in just one of the two surveys. To avoid the loss of less healthy subjects and the subsequent bias in effect estimate, the 1985 data were analysed cross sectionally with the inclusion of data from 1979 for those subjects who had not been followed up in the last survey. The subjects with work experience in the pulp mill had mean levels of forced expiratory volume in one second $\left(\mathrm{FEV}_{1}\right)$ and forced vital capacity $(\mathrm{FVC})$ lower than those of unexposed subjects who had never worked in the pulp or paper production areas. Based on parameter estimates from regression analysis, each year of employment in the pulp operation was associated with a $-5.8 \mathrm{ml}$ change in $\mathrm{FEV}_{1}(\mathrm{p}=0.08)$ and $\mathrm{a}-7.2 \mathrm{ml}$ change in FVC $(\mathrm{p}=0.04)$. Ninety one per cent of the subjects with pulp mill experience had terminated employment in that area of the company, so the association with decreased lung function appears to be a non-reversible effect that persisted after the cessation of exposure.

Employment in pulp and paper operations entails exposure to several airborne chemicals. In chemical pulping operations workers are exposed to various irritant gases, including sulphur dioxide, hydrogen sulphide, methyl mercaptan, chlorine, and chlorine dioxide. In paper mills workers may be exposed to paper dust and to the various fillers and additives added to the pulp mixture before the making of the paper.

Cross sectional studies of pulmonary function among pulp and paper production workers have yielded inconsistent findings. In two studies conducted in Finland no differences in pulmonary function were noted when comparing chlorine plant workers with other paper company employees. ${ }^{2}$ From a Canadian study, the spirometry results for subjects who worked in a sulphite pulp mill or a paper mill were similar to those for the unexposed workers. ${ }^{3}$ In another study in Canada, among young non-smokers, bleachery workers had significantly lower values for both the maximal mid-expiratory flow rate and the ratio of the forced

Accepted 19 December 1988 expiratory volume in one second and forced vital capacity $\left(\mathrm{FEV}_{1} / \mathrm{FVC}\right)$ compared with unexposed railyard workers. ${ }^{4}$ In the same study, among older subjects, maintenance workers had decreased FVC in comparison with the railyard workers. Subjects from the sulphate pulp mill, however, had spirometry results that did not significantly differ from those of railyard workers. A study in Norway showed that among subjects aged under 50 , sulphite pulp mill workers had decreased maximal expiratory flow rates relative to paper mill workers. ${ }^{5}$

In the current study subjects from a 24 year prospective study of respiratory health in Berlin, New Hampshire, are used to examine pulmonary function among employees from the local paper company. The subjects were initially tested in the 1960 s and then reexamined at regular intervals. The results from a subset of the current study population have been published. ${ }^{67}$ Those papers reported some respiratory problems in workers, particularly among employees in the pulping process. The data used for this study are from the two most recent field surveys conducted in 1979 and 1985. This study differs from the earlier 
studies in that it includes more subjects and improved comparison groups.

The goals of this study were:

(1) To test whether the pulmonary function values for subjects who worked in the pulp production areas of a paper company were lower than those of unexposed subjects.

(2) To examine how non-participation in the follow up surveys was related to respiratory health and how it may bias effect estimates.

\section{Methods}

\section{STUDY POP.ULATION}

A prospective study of respiratory health was initiated in Berlin, New Hampshire, in the 1960s. A total of 1098 white male subjects participated in at least one of the field surveys. There were 827 white men who were enrolled from the general population, first tested in either 1961 or 1967 , and then invited to follow up surveys every six years. ${ }^{89}$ Another 271 white men, selected from the workers at the local paper company, were first tested in 1963, and then retested in 1973, 1979 , and $1985 .^{6}$ The results from testing the paper company group were published after the 1963 and 1973 field surveys. ${ }^{67}$ At each survey, subjects were tested by means of an interviewer administered questionnaire and a pulmonary function test (PFT). The questionnaire inquired about respiratory symptoms and diseases, smoking history, and work history.

The white men from the Berlin study were included in the current study if they met the following selection criteria:

(1) Participated in a follow up survey in either 1979 or 1985.

(2) Worked at least one year at the paper company in Berlin, New Hampshire.

(3) Worked less than five years in pulp and paper production in other paper companies.

(4) Met the reproducibility criteria for pulmonary function test results in 1979 or 1985.

In addition to the 271 subjects enrolled in 1963, another 612 of the 827 men enrolled from the general population in 1961 and 1967 had also worked in the paper company at some time. By considering all the $\overline{\bar{z}}$ men surveyed in Berlin, regardless of when they were enrolled, the current study included more subjects $\$$ than the earlier analyses of the paper company group.

\section{OCCUPATIONAL EXPOSURE}

The sulphite pulp process was used by the paper? company in Berlin, New Hampshire, from the late $\overline{\overline{0}}$. nineteenth century up to 1963 . The sulphate pulping process was first used in 1948 and expanded after the $\propto$ sulphite operation was discontinued. The companyos stopped manufacturing chlorine by 1966 but con- $\overrightarrow{0}$ tinued to purchase it for use as a bleaching agent for $\overrightarrow{-}$ pulp.

Measurements of airborne contaminants were conducted in the sulphite pulp mill and chlorine com- $\frac{\mathbb{D}}{3}$ pound areas in 1958,1962, and 1963, and in the sulphate pulp mill in 1963 . The concentrations of sulphur dioxide and chlorine decreased over those five $\overrightarrow{-}$ years from 1958 to 1963 (table 1). The downward trend $\gamma$ was probably attributable to changes in processes and $\%$ control devices instituted in the late 1950s and early윽 1960s. As indicated in table 1 , the exposure levels in1963 were within the 1985 OSHA standards. ${ }^{10} \mathrm{O}$ Additional process changes have been introduced in the company since 1963 , which may have reduced 3 overall exposure levels. Unfortunately, no otherष्ठ measurements of airborne contaminants were avail- $\vec{\theta}$ able from the company.

With so few exposure measurements, occupational exposure variables were based entirejy응 on the lifetime work histories from the survey questionnaires. Subjects were assigned to the following three occupational categories according to their work experience in the paper company in Berlin, New@ Hampshire:

(1) Ever worked at least one year in the pulp mill. 윽

(2) Ever worked at least one year in the paper mill.

(3) Ever worked at least one year in the papero company but never in the pulp or paper mill-that is, the unexposed subjects.

Subjects could be included in both the pulp mill and: the paper mill categories, but the unexposed category 3 . was exclusive of the other two groups.

Work in the pulp mill was further characterised by

Table 1 Exposure levels (ppm) for selected airborne substances from the pulp operation in Berlin, New Hampshire*

\begin{tabular}{|c|c|c|c|c|c|c|c|}
\hline \multirow[b]{2}{*}{ Compound } & \multirow{2}{*}{$\begin{array}{l}\text { OSHA } \\
\text { standard } \\
\text { in } 1985\end{array}$} & \multicolumn{3}{|c|}{ Mean exposure levels } & \multicolumn{3}{|c|}{ Max exposure levels } \\
\hline & & 1958 & 1962 & 1963 & 1958 & 1962 & 1963 \\
\hline $\begin{array}{l}\text { Sulphur dioxide } \\
\text { Chlorine }\end{array}$ & $\begin{array}{l}5 \dagger \\
5 t\end{array}$ & $\begin{array}{r}13 \\
7\end{array}$ & $\frac{4}{\text { Trace }}$ & $\begin{array}{l}2 \\
<0.009\end{array}$ & $\begin{array}{l}33 \\
64\end{array}$ & $\stackrel{8}{\text { Trace }}$ & $\begin{array}{l}7 \\
\text { Trace }\end{array}$ \\
\hline
\end{tabular}

ppm $=$ parts per million.

*Adapted from table III, Ferris et al. ${ }^{6}$

OSHA standards as of $1985 .^{10}$

†Eight hour time weighted average.

fCeiling level. 
area of pulping process-that is the sulphite mill, sulphate mill, or the chlorine operation - and number of years of employment. Subjects who worked in the sulphite and sulphate pulp mills were exposed to sulphur dioxide, hydrogen sulphide, and other sulphur compounds. Subjects from the chlorine operation had worked in either the manufacture or use of chlorine and chlorine dioxide.

\section{PULMONARY FUNCTION TESTING}

The pulmonary function of subjects was evaluated using water filled survey recording spirometers. The same spirometers were used at the surveys in 1979 and 1985. At each field survey, the spirometers were calibrated against each other during use and observed to agree within $1 \%$ or better. The field survey personnel were given strict instructions on how to administer the test to ensure that the measurements were performed in a standard fashion. ${ }^{112}$ The spirometry was conducted with the subject sitting and without a nose clip. Usually, five trials were done for each subject. The tracings were read by hand and corrected to BTPS. Height was measured with a right angle while the subject stood in stockinged feet against a wall.

The rules for the reproducibility of both the FEV and the FVC were developed by the Six Cities Study ${ }^{13}$ :

(1) If the first and second largest values were within $200 \mathrm{ml}$ then the test was acceptable.

(2) If rule 1 was not met the largest value was discarded and the test was reproducible if the second and third largest blows were within $200 \mathrm{ml}$.

(3) If first rule 1 and then rule 2 were not fulfilled then the test was unacceptable.

The maximum value was determined from the pair of results that met the $200 \mathrm{ml}$ criterion.

Prediction equations from the Six Cities Study were initially considered for application in this study. ${ }^{14}$ The Six Cities Study and the study in Berlin, New Hampshire, were initiated by the same researcher, used the same spirometers and research protocols, and employed many of the same field survey personnel. The subjects from the current study had mean per cent predicted $\mathrm{FEV}_{1}$ and FVC of $101 \%$ and $98 \%$, respectively, based on the equations of the Six Cities Study. Nevertheless, some important differences in age distribution and cigarette smoking existed between the two study populations. The prediction equations from the Six Cities Study were developed using spirometry results from adults who were under 75 and among whom the mean age was about 50 . In the current study approximately $20 \%$ of the subjects were 75 or older and the mean age was 64 . Also, the current study population had many more former smokers and many fewer current smokers, proportionally, than the subjects from the Six Cities Study. Given these differences, the prediction equations from the Six
Cities Study were not used.

Instead, prediction equations for $\mathrm{FEV}_{1}$ and FVC were developed using data from the subjects in the current cross sectional study. The PFT values for each subject were then expressed as percentages of predicted values. The prediction equations included the same covariates as those used in the equations developed by the Six Cities Study ${ }^{14}$ : age, age ${ }^{2}$, current packs of cigarettes smoked each day, and lifetime pack-years of cigarettes smoked. Age was centred on 65 years, which was about the mean age of the study cohort. For the lifetime smoking covariate, a pack-year is equal to smoking one pack of 20 cigarettes each day for one year. The maximum FEV 1 and FVC were adjusted to the height of a typical subject who was 1.73 metres tall. This was accomplished by dividing the maximum $\mathrm{FEV}_{1}$ or FVC by the square of the subject's height in metres and then multiplying by $(1.73 \text { metre })^{2}$.

The prediction equations for $\mathrm{FEV}_{1}$ and FVC were: $\left(\mathrm{FEV}_{1} / \mathrm{ht}^{2}\right) \times(1 \cdot 73)^{2}=$

$2843.8-37.7$ (age-65) +0.11 (age-65) ${ }^{2}-23.2$ (current packs/day cig) -6.3

$\left(\mathrm{FVC} / \mathrm{ht}^{2}\right) \times(1.73)^{2}=$

$3623.8-39 \cdot 3\left(\right.$ age-65) $+0.28(\text { age-65) })^{2}-6 \cdot 4$ (current packs/day cig) - 3.8 (lifetime pack-years cig)

The $R^{2}$ values for the two equations were 0.28 and $0 \cdot 26$, respectively.

NON-PARTICIPATION IN 1979 AND 1985 SUR VEYS

The protocol for the Berlin study dictated that the field survey staff should encourage subjects to complete both the questionnaire and the PFT. In 1979 that protocol was not strictly followed. The field survey staff readily accepted a subject's refusal when he expressed doubt about performing the PFT. In such cases the subject was often interviewed but the PFT was not performed.

Failure to participate may also have been due to the poor health of the subject. The relative healthiness of the subjects who were tested in only one of the two surveys conducted in 1979 and 1985 was evaluated by comparing their mean PFT values with the results for the subjects who were tested in both surveys. Also, the potential bias associated with non-participation was evaluated by examining the association of occupational exposure with decreased pulmonary function in the cross sectional data, first among the subjects who were tested in both 1979 and 1985 and then among the subjects who were tested only once.

\section{STATISTICAL ANALYSIS}

The analysis of longitudinal change from 1979 to 1985 was necessarily limited to the subjects who were tested at both surveys. The analysis of cross sectional data was based on the results from the 1985 survey. In addition, for the subjects who participated in 1979 but 
not in 1985 data from the 1979 survey were used. Using the additional data from 1979 helped to minimise the loss of information that resulted from subjects who were lost to follow up in 1985.

T statistics were used to test for significant differences in mean per cent predicted pulmonary function between occupational groups. Least squares linear regression analysis was also used to estimate effects on pulmonary function and test for statistical significance. All statistical analysis was done on a personal computer using programs from SAS..$^{15}$

\section{Results}

\section{FREQUENCY OF PARTICIPATION}

There were 232 subjects from the 1979 survey and 278 from the 1985 survey who fulfilled the selection criteria (table 2). The subjects from the two field surveys represent 339 individuals, of whom 61 were tested only in 1979, 107 only in 1985, and 171 in both surveys. Of the 61 tested only in 1979, 26 had died by the 1985 survey and the remaining 35 were alive but not resurveyed. Among the 107 subjects successfully tested with PFT only in 1985, 57 missed the 1979 survey and the other 50 completed only the questionnaire in 1979.

Each of the four groups of subjects tested only once had significantly lower mean per cent predicted FVC than those tested in both 1979 and 1985 (table 3). Similar results were also observed for $\mathrm{FEV}_{1}$. In addition, effect estimates were biased as a result of non-participation. The effect of occupational exposure on PFT was diminished among the 171 subjects tested twice when compared with the effect evident among the 168 subjects who were tested only once (table 4). In particular, the difference in mean per cent predicted FVC between the pulp mill and unexposed subjects was less among subjects tested twice than among subjects tested only once. A similar pattern was observed for $\mathrm{FEV}_{1}$. Further analysis showed that this bias was because pulp mill workers with low lung function were more likely to have participated only once than were the unexposed workers with low lung function.

\section{LONGITUDINAL RESULTS}

Among the 171 subjects tested in both 1979 and 1985, 120 did not smoke cigarettes during the six years between surveys. The mean annual changes in FEV, and FVC for the non-smokers showed little variation by type of paper company employment and whether the employment was past (before 1979) or recent (from 1979 to 1985) (table 5). There was some indication that subjects with recent pulp mill experience had a greater mean decline in $\mathrm{FEV}_{1}(-41 \mathrm{ml} / \mathrm{y})$ and that recent paper mill workers had a relatively small mean decline in FVC $(-14 \mathrm{ml} / \mathrm{y})$ compared with unexposed subjects. Linear regression analysis was conducted $\overline{\bar{B}}$ with all 171 subjects, controlling for age and cigaretter smoking, with the outcomes of annual changes in FEV $_{1}$ and FVC. For both pulp mill and paper mills: employment, years worked before 1979 and years? worked from 1979 to 1985 were not associated witho statistically significant changes in PFT.

\section{CROSS SECTIONAL RESULTS}

In the cross sectional analysis, data from the 1985 survey were used for the 278 subjects tested that year? and data from the 1979 survey for the 61 subjects tested in 1979 but not in 1985. The inclusion of the $\overrightarrow{-}$ subjects tested only in 1979 minimised both the loss of less healthy subjects and the subsequent bias in the्ष effect estimate.

The three occupational categories were similar withis respect to mean age, but the pulp mill category had a higher percentage of retirees $(57 \%)$ than the paper milF $(47 \%)$ and unexposed (45\%) categories (table 6). Also compared with the unexposed subjects, the subjects ino the pulp mill and paper mill groups had a smaller? proportion of current smokers and lower levels of cumulative and current cigarette smoking. The 3390 subjects had spent a mean of 32 years working in the paper company.

The pulp mill subjects had lower mean per cent predicted FEV, and FVC than the unexposed subjegts (table 7). The mean values for the pulp mill categefy were $98 \%$ for both $\mathrm{FEV}_{1}$ and FVC, whereas unexposed subjects had $103 \%$ for $F_{E V}$ and $102 \%$ FVC. These differences by occupation were not stafistically significant by $t$ test $\left(\mathrm{p}=0 \cdot 12\right.$ for $\mathrm{FEV}_{1}$ and $\mathrm{p}=\overline{\mathrm{D}}$ $0 \cdot 18$ for FVC). The mean per cent predicted values for the paper mill category were $101 \%$ for both $F E V_{1}$ and FVC, which were between those for the other two $\overrightarrow{\overrightarrow{0}}$ occupational groups. The results for the $\mathrm{FEV}_{1} / \mathrm{FVC}^{3}$ ratio were similar among the three categories.

Experience in the pulp mill was further delineated by different work areas (table 7). The subjects in theo pulp mill category had worked a mean of 17 years in that part of the company, with an average of nine yearso in the sulphite mill, five years in the sulphate mill, and. three years in the chlorine operation. The subjects ino the sulphate mill group had the lowest mean per cent predicted FEV,$(94 \%)$ and FVC $(96 \%)$ of the threeo areas, and the value for FEV , was significantly less than the comparable value of $103 \%$ for the unexposedo subjects $(\mathrm{p}<0.05)$.

The 166 subjects with pulp mill experience had lefî that operation a mean of 19 years earlier, and only 150 subjects (or $9 \%$ of 166 ) were still employed in the pulp mill at the time of their most recent survey. Also, $69 \%$ of the time worked in the pulp mill occurred before 1964 , which largely preceded the documented drop in concentrations of airborne contaminants (table 1) 
Table 2 Selection of subjects for current study

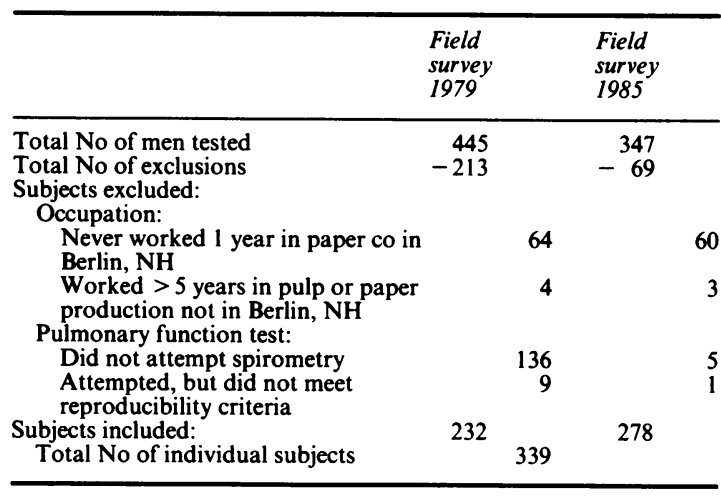

The 151 subjects with pulp mill experience who no longer worked in that area had mean per cent predicted FEV $(97 \%, \mathrm{SE}=2 \cdot 1)$ and $\mathrm{FVC}(98 \%, \mathrm{SE}=1 \cdot 7)$ that were slightly less than the values for all pulp mill subjects.

\section{REGRESSION ANALYSES}

There was an inverse relation between the number of years worked in the pulp operation and the mean per cent predicted $F E V_{1}$ and FVC. By contrast, the number of years worked in either the paper mill or in unexposed parts of the paper company were not predictive of a decrement in pulmonary function.

The effect of years worked in the pulp operation was analysed with least squares linear regression, using the 166 subjects from the pulp mill category and the 76 subjects with no pulp or paper mill exposure (table 8). A series of models were fitted to height adjusted FEV and FVC that included covariates for pulp mill exposure as well as the four covariates for age and cigarette smoking as used in the prediction equations.

Each year in the pulping process was associated with a $5.8 \mathrm{ml}$ decrease in $\mathrm{FEV}_{1}(\mathrm{p}=0.08)$ and a $7.2 \mathrm{ml}$ decrease in FVC $(p=0.04)$ (model $A$, table 8). In a regression model with covariates for number of years in sulphur compound jobs (in the sulphite and sul- phate mills) and number of years in chlorine jobs the two parameter estimates were similar when the outcome was $\mathrm{FEV}_{1}$ (model B, table 8). Specifically, the estimated changes were $-5.9 \mathrm{ml}(p=0.11)$ a year of sulphur compound work and $-5.5 \mathrm{ml}(\mathrm{p}=0.38)$ a year of chlorine work. With the outcome FVC, the parameter estimate for the sulphur compound work was $-8.1 \mathrm{ml}$ a year, which was statistically significant $(p=0.03)$. The comparable parameter estimate for the chlorine years was smaller and the $p$ value was large $(-4.0 \mathrm{ml}$ a year, $\mathrm{p}=0.55)$.

In a model with covariates for years worked in the sulphite, sulphate, and chlorine operations, none of the parameter estimates was statistically significant (model C, table 8). Nevertheless, similar to the results for mean per cent predicted PFT, sulphate mill work had a larger annual decrement in $\mathrm{FEV}_{1}(-7.9 \mathrm{ml} / \mathrm{y}, \mathrm{p}$ $=0.12)$ than work in the sulphite $\operatorname{mill}(-4.2 \mathrm{ml} / \mathrm{y}, \mathrm{p}=$ $0.35)$ or work in the chlorine operation $(-5.7 \mathrm{ml} / \mathrm{y}, \mathrm{p}$ $=0 \cdot 37$ ).

\section{Discussion}

\section{PULP MILL EXPOSURES}

The subjects with work experience in the pulp mill had values for $\mathrm{FEV}_{1}$ and FVC that were lower than those of the unexposed subjects. Moreover, $91 \%$ of the pulp mill subjects had terminated employment in that operation. Thus past pulp mill work was associated with a non-reversible decrement in lung function that persisted after the cessation of exposure.

Table 4 Effect of occupational exposure on FVC by frequency of participation

\begin{tabular}{|c|c|c|c|c|c|c|}
\hline \multirow[b]{2}{*}{ Occupation } & \multicolumn{3}{|c|}{$\begin{array}{l}\text { Tested in both } \\
1979 \text { and } 1985\end{array}$} & \multicolumn{3}{|c|}{$\begin{array}{l}\text { Tested once in } \\
1979 \text { or } 1985\end{array}$} \\
\hline & No & $F V C^{*}$ & $(S E)$. & No & $F V C^{*}$ & $(S E)$ \\
\hline $\begin{array}{l}\text { Unexposed } \\
\text { Ever pulp mill } \\
\text { Diff in \% pred }\end{array}$ & $\begin{array}{l}40 \\
83\end{array}$ & $\begin{array}{l}105 \% \\
104 \% \\
1 \\
t=0.3 \\
\mathrm{p}=0 .\end{array}$ & $\begin{array}{l}(3 \cdot 3) \\
(2 \cdot 4)\end{array}$ & $\begin{array}{l}36 \\
83\end{array}$ & $\begin{array}{l}98 \% \\
92 \% \\
6 \\
t=1.6 \\
\mathrm{p}=0.12\end{array}$ & $\begin{array}{l}(4 \cdot 2) \\
(2 \cdot 9)\end{array}$ \\
\hline
\end{tabular}

*Mean per cent predicted FVC.

Table 3 Mean per cent predicted FVC (SE) by participation status in the 1979 and 1985 surveys

\begin{tabular}{|c|c|c|c|c|}
\hline \multicolumn{2}{|c|}{ PFT only in 1979} & \multicolumn{2}{|c|}{ PFT only in 1985} & \multirow{3}{*}{$\begin{array}{l}P F T \text { in both } \\
1979 \text { and } 1985^{*} \\
(n=171)\end{array}$} \\
\hline \multicolumn{2}{|c|}{ Still alive in $1985 ?$} & \multicolumn{2}{|c|}{ Questionnaire in 1979? } & \\
\hline $\begin{array}{l}N o \\
(n=26)\end{array}$ & $\begin{array}{l}Y e s \\
(n=35)\end{array}$ & $\begin{array}{l}N o \\
(n=57)\end{array}$ & $\begin{array}{l}Y e s \\
(n=50)\end{array}$ & \\
\hline $92 \%+(5 \cdot 0)$ & $95 \%+(3 \cdot 7)$ & $97 \%+(2 \cdot 7)$ & $96 \%+(2 \cdot 5)$ & $105 \%(1.4)$ \\
\hline
\end{tabular}

*Data from the 1985 survey.

tp $<0.05$, by $t$ statistic, testing the null hypothesis that the mean value is equal to that of the subjects tested in both 1979 and 1985. 
Table 5 Mean annual change ( $\mathrm{ml} / \mathrm{y})$ of FEV and FVC from 1979 to 1985 among non-smokers, by occupation

\begin{tabular}{|c|c|c|c|c|c|}
\hline \multirow[b]{2}{*}{ Timing and type of work } & \multirow[b]{2}{*}{ No } & \multicolumn{2}{|l|}{$F E V_{1}$} & \multicolumn{2}{|c|}{ FVC slope } \\
\hline & & Mean & $(S E)$ & Mean & $(S E)$ \\
\hline $\begin{array}{l}\text { Work before } 1979 \text { only: } \\
\text { Paper mill* } \\
\text { Pulp mill* } \\
\text { Work during 1979-85: }\end{array}$ & $\begin{array}{l}35 \\
37\end{array}$ & $\begin{array}{l}-20 \\
-20\end{array}$ & $\begin{array}{l}(10 \cdot 8) \\
(10 \cdot 2)\end{array}$ & $\begin{array}{l}-17 \\
-26\end{array}$ & $\begin{array}{r}(10.2) \\
(9.9)\end{array}$ \\
\hline $\begin{array}{l}\text { Paper mill } \dagger \\
\text { Pulp mill } \dagger \\
\text { Never pulp or paper mill }\end{array}$ & $\begin{array}{l}23 \\
15 \\
25\end{array}$ & $\begin{array}{l}-25 \\
-41 \\
-27\end{array}$ & $\begin{array}{r}(11 \cdot 2) \\
(9 \cdot 0) \\
(8 \cdot 8)\end{array}$ & $\begin{array}{l}-14 \\
-31 \\
-34\end{array}$ & $\begin{array}{l}(14 \cdot 2) \\
(9 \cdot 6) \\
(12 \cdot 5)\end{array}$ \\
\hline Total & 120 & -26 & $(4 \cdot 5)$ & -24 & $(5 \cdot 1)$ \\
\hline
\end{tabular}

*Fourteen subjects were considered in both the pulp and paper mill categories for work before 1979 only.

†One subject was considered in both the pulp and paper mill categories for work during 1979-85.

Table 6 Descriptive characteristics of subjects by occupation

\begin{tabular}{|c|c|c|c|}
\hline & $\begin{array}{l}\text { Unexposed } \\
(n=76)\end{array}$ & $\begin{array}{l}\text { Ever paper } \\
\text { mill } \\
\left(n=173^{*}\right)\end{array}$ & $\begin{array}{l}\text { Ever pulp } \\
\text { mill } \\
\left(n=166^{*}\right)\end{array}$ \\
\hline $\begin{array}{l}\text { Age }(y): \\
\%<50 \\
\% 50-9 \\
\% 60-9 \\
\% \geqslant 70 \\
\text { Mean age }(y): \\
\% \text { Retired } \\
\text { Cigarettes: }\end{array}$ & $\begin{array}{l}9 \% \\
33 \% \\
30 \% \\
28 \% \\
63 \\
45 \%\end{array}$ & $\begin{array}{l}3 \% \\
38 \% \\
34 \% \\
25 \% \\
63 \\
47 \%\end{array}$ & $\begin{array}{l}2 \% \\
30 \% \\
34 \% \\
34 \% \\
65 \\
57 \%\end{array}$ \\
\hline $\begin{array}{l}\text { Cigarettes: } \\
\% \text { Never smoked } \\
\% \text { Formerly smoked } \\
\% \text { Currently smoke } \\
\text { Mean life (p-y)† } \\
\text { Mean packs a day }\end{array}$ & $\begin{array}{c}21 \% \\
51 \% \\
28 \% \\
32 \\
1 \cdot 3\end{array}$ & $\begin{array}{c}16 \% \\
64 \% \\
20 \% \\
24 \\
1 \cdot 2\end{array}$ & $\begin{array}{c}15 \% \\
69 \% \\
16 \% \\
21 \\
1 \cdot 1\end{array}$ \\
\hline
\end{tabular}

Table 7 Mean per cent predicted FEV $V_{1}$ and FVC by type of paper company work

\begin{tabular}{|c|c|c|c|c|c|c|c|}
\hline \multirow{3}{*}{$\begin{array}{l}\text { Type of paper } \\
\text { company work } \\
\text { Unexposed } \\
\text { Ever paper mill } \\
\text { Ever pulp mill } \\
\text { Pulp mill area: }\end{array}$} & \multirow{3}{*}{$\begin{array}{c}\text { No } \\
76 \\
173^{*} \\
166^{*}\end{array}$} & \multicolumn{6}{|c|}{ Mean per cent predicted (SE) } \\
\hline & & \multicolumn{2}{|c|}{$F E V_{1}$} & \multicolumn{2}{|c|}{$F V C$} & \multicolumn{2}{|c|}{$F E V_{1} / F V C$} \\
\hline & & $\begin{array}{r}103 \\
101 \\
98\end{array}$ & $\begin{array}{l}(2.7) \\
(1.9) \\
(1.9)\end{array}$ & $\begin{array}{r}102 \\
101 \\
98\end{array}$ & $\begin{array}{l}(2 \cdot 0) \\
(1 \cdot 5) \\
(1 \cdot 6)\end{array}$ & $\begin{array}{r}101 \\
100 \\
99\end{array}$ & $\begin{array}{l}(1.6) \\
(0.9) \\
(1.0)\end{array}$ \\
\hline $\begin{array}{l}\text { Sulphite mill } \\
\text { Sulphate mill } \\
\text { Chlorine mill }\end{array}$ & $\begin{array}{r}124 \\
44 \\
37\end{array}$ & $\begin{array}{c}99 \\
94 \ddagger \\
100\end{array}$ & $\begin{array}{l}(2 \cdot 2) \\
(3 \cdot 6) \\
(4 \cdot 0)\end{array}$ & $\begin{array}{r}99 \\
96 \\
100\end{array}$ & $\begin{array}{l}(1 \cdot 8) \\
(3 \cdot 2) \\
(3 \cdot 4)\end{array}$ & $\begin{array}{r}100 \\
98 \\
100\end{array}$ & $\begin{array}{l}(1 \cdot 1) \\
(1 \cdot 9) \\
(2 \cdot 0)\end{array}$ \\
\hline
\end{tabular}

* Seventy six subjects were considered in both the pulp mill and paper mill categories.

$\dagger$ Thirty seven of the 166 subjects in the pulp mill category worked in more than one of the three different areas: 16 sulphite and sulphate, 18 sulphite and chlorine, 1 sulphite and chlorine, 2 sulphite, sulphate, and chlorine.

$\ddagger \mathrm{p}<0.05$, by $t$ statistic, testing the null hypothesis that the mean value is equal to that of the unexposed subjects.
Table 8 Regression estimates of the effect on FEV and FVC of years worked in the pulp mill*

\begin{tabular}{|c|c|c|c|c|}
\hline \multirow[b]{2}{*}{$\begin{array}{l}\text { Pulp mill } \\
\text { covariates } \dagger\end{array}$} & \multicolumn{2}{|l|}{$F E V_{1}$} & \multicolumn{2}{|l|}{$F V C$} \\
\hline & $\begin{array}{l}\text { Parameter } \\
\text { estimate }\end{array}$ & $(p)$ & $\begin{array}{l}\text { Parameter } \\
\text { estimate }\end{array}$ & $(p)$ \\
\hline $\begin{array}{l}\text { Model A: } \\
\text { Total years pulp mill } \\
\text { Model B: }\end{array}$ & $-5 \cdot 8$ & $(0.08)$ & $-7 \cdot 2$ & $(0 \cdot 04) \stackrel{\text { }}{\stackrel{\mathrm{\Phi}}{ }}$ \\
\hline $\begin{array}{l}\text { Sulphur pulp work (y) } \\
\text { Chlorine pulp work (y) }\end{array}$ & $\begin{array}{l}-5.9 \\
-5 \cdot 5\end{array}$ & $\begin{array}{l}(0 \cdot 11) \\
(0 \cdot 38)\end{array}$ & $\begin{array}{l}-8 \cdot 1 \\
-4 \cdot 0\end{array}$ & 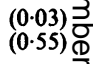 \\
\hline $\begin{array}{l}\text { Model C: } \\
\text { Years in sulphite mill } \\
\text { Years in sulphate mill } \\
\text { Years in chlorine pulp } \\
\text { work }\end{array}$ & $\begin{array}{l}-4 \cdot 2 \\
-7.9 \\
-5 \cdot 7\end{array}$ & $\begin{array}{l}(0 \cdot 35) \\
(0 \cdot 12) \\
(0 \cdot 37)\end{array}$ & $\begin{array}{l}-7 \cdot 8 \\
-8 \cdot 3 \\
-4 \cdot 0\end{array}$ & 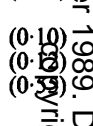 \\
\hline
\end{tabular}

*These analyses included 242 subjects: 166 who had ever worked in the pulp mill and 76 who had never worked in the pulp or paper mill. The units for each parameter estimate are millilitres per year of work.

tEach linear regression model also included the following four $\mathbb{D}$ covariates: age-65, (age-65) $)^{2}$, current packs of cigarettes smoked a day, lifetime pack-years of cigarettes smoked. The dependent $\vec{F}$ variables FEV, and FVC were both height adjusted.

There was an inverse relation between lung function: and the number of years of pulp mill employment (table 8). The individuals who were sensitive to the 3 irritant gases such as sulphur dioxide and chlorine in the pulp mill probably did not remain in that area. Indeed, there is evidence in the personnel records of 0 the paper company in Berlin, New Hampshire, that $₹$ the management attempted to accommodate the pulp윽 mill workers who were bothered by gases and vapours $\supset$ by transferring them to other jobs within the company. 을. Thus the subjects in the current study who remained in jobs in the pulp mill were probably the individuals who. were least reactive to the irritant gases.

\section{COMPARISON WITH PREVIOUS STUDIES OF THE}

PAPER COMPANY

Previous reports of the paper company workers in Berlin, New Hampshire, included only the 271 subjects ? 
who were enrolled in 1963. By considering all the men surveyed in Berlin, regardless of when they were enrolled, the current study included more subjects.

In earlier reports on the employees from the paper company in Berlin pulp mill workers were usually compared with either the paper mill workers or subjects from the general population. ${ }^{67}$ There were problems of misclassification of exposure with both comparison groups. As discussed in previous reports, several of the paper mill subjects had worked in the pulp mill before transferring to the paper operation. ${ }^{6}$ Also, as noted above, many of the men selected from the general population of Berlin had worked in the paper company and some were employed in the production of pulp and paper. The presence of subjects with pulp mill experience in the "unexposed" comparison group would bias any measure of effect to the null. In the current study an attempt was made to minimise misclassification by redefining the comparison population. In particular, the comparison group is composed of subjects who had worked in the paper company but had never worked in the pulp or paper production areas.

There are findings from the current study of subjects from the 1979 and 1985 surveys consistent with the findings reported after the surveys of 1963 and 1973. One concerned the effect of accumulated work experience. For subjects aged 50 and older in the 1963 survey, those working in the pulp mill had lower per cent predicted FVC values than did those working in the paper mill. ${ }^{6}$ Similarly, in the 1973 testing it was observed that among the subjects who retired between 1963 and 1973 the workers from the pulp operation had lower FEV 1 and FVC than did those who had formerly worked in the paper mill. ${ }^{7}$ In both these earlier reports the age specific findings probably reflected the fact that the older pulp mill workers had accumulated the most years of work in exposed jobs. Similarly, in the current study pulmonary function varied inversely with the number of years worked in the pulp mill.

A new finding from the current study is that the mean $\mathrm{FEV}_{1}$ and $\mathrm{FVC}$ for the sulphate mill group were lower than the comparable values for the sulphite mill group. This observation was unexpected, given that exposure concentrations of sulphur dioxide were usually higher in the sulphite mill. ${ }^{6}$ The measures of airborne contaminants cover a short period, however, and provide a limited basis for evaluating the historical exposures that occurred over several decades in both mills.

LONGITUDINAL ANALYSIS AND FUTURE WORK The longitudinal analysis was limited to subjects who participated in both the two consecutive surveys (1979 and 1985) which occurred several years after the prospective study was initiated. Based on cross sectional data, these subjects were healthy survivors (table 3), among whom the effect of occupational exposure was diminished (table 4). Similarly, the longitudinal analysis showed no significant differences by occupation. By going beyond the last two surveys and examining longitudinal data from the entire 24 years of the prospective study, the exclusion of subjects would be minimised and the amount of data per subject would be maximised.

Using the data from all the field surveys would make possible the evaluation of change in PFT during and after occupational exposure. The lower pulmonary function associated with past pulp mill employment observed in the cross sectional data could have resulted from an accelerated rate of decline while the subjects were still exposed. At the end of exposure, the rate of decline may have slowed to a more "normal" level. These issues could be addressed by using all the available data starting with the first survey in 1961 .

The finding of an association between past pulp mill work and lower lung function raises the issue of the safety of current pulp mill employment. As noted, the study cohort contains few subjects who are currently working in the pulp mill. To study the relation between recent employment in the paper company and pulmonary function, it would be necessary to test current employees. It would also be necessary to conduct the appropriate air monitoring studies in order to estimate concentrations of substances such as sulphur dioxide, hydrogen sulphide, and chlorine.

Supported in part by grants to the Harvard School of Public Health from the Mobil Foundation, the Electrical Power Research Institute (grant No RP 100101), the National Institute of Environmental Health Sciences (grants No ES-01108-14 and ES-0002), and the Environmental Protection Agency (cooperative agreement CR-811650). Dr Henneberger was supported by a National Research Service Award from the National Institute of Environmental Health Sciences (grant No 5 T32 ES 07069).

\section{References}

1 Huhti E, Ryhanen P, Vuopala U, Takkunen J. Chronic respiratory disease among pulp mill workers in an arctic area in northern Finland. Acta Med Scand 1970;187:433-44.

2 Poukkula A, Huhti E, Makarainen M. Chronic respiratory disease among workers in a pulp mill: a ten-year follow-up study. Chest 1982;81:285-9.

3 Chan-Yeung M, Wong R, Maclean L, et al. Respiratory survey of workers in a pulp and paper mill in Powell River, British Columbia. Am Rev Respir Dis 1980;122:249-57.

4 Enarson DA, Maclean L, Dybuncio A, et al. Respiratory health at a pulpmill in British Columbia. Arch Environ Health 1984;39:325-30. 
5 Skalpe IO. Long term effects of sulphur dioxide exposure in pulpmills. Br J Ind Med 1964;21:69-73.

6 Ferris BG Jr, Burgess WA, Worcester J. Prevalence of chronic respiratory disease in a pulp mill and a paper mill in the United States. Br J Ind Med 1967;24:26-37.

7 Ferris BG Jr, Puleo S, Chen HY. Mortality and morbidity in a pulp and paper mill in the United States: a ten year follow-up. Br J Ind Med 1979;36:127-34.

8 Ferris BG Jr, Anderson DO. The prevalence of chronic respiratory disease in a New Hampshire town. Am Rev Respir Dis 1962;86:165-85.

9 Ferris BG Jr, Higgins ITT, Higgins MW, Peters JM, Van Ganse WF, Goldman MD. Chronic nonspecific respiratory disease, Berlin, New Hampshire, 1961-1967: a cross-sectional study. Am Rev Respir Dis 1971;104:232-44.

10 National Institute for Occupational Safety and Health. NIOSH pocket guide to chemical hazards. Washington: US Government
Printing Office, 1985. (DHEW (NIOSH) publ No 78-210.)

11 Ferris BG Jr (principal investigator). Epidemiology standardization project. Am Rev Respir Dis 1978;118 (part 2):55-88.

12 Ferris BG Jr, Speizer FE, Bishop Y, Prang G, Weener J.@ Spirometry for an epidemiologic study: deriving optimum $\Rightarrow$ summary statistics for each subject. Bull Eur Physiopathol $\overrightarrow{\vec{S}}$ Respir 1978;14:145-66.

13 Eisen EA, Dockery DW, Speizer FE, Fay ME, Ferris BG Jr. The association between health status and the performance of $\frac{\overline{\bar{C}}}{\mathrm{n}}$ excessively variable spirometry tests in a population-based $\frac{\overline{\mathcal{S}}}{\mathcal{C}}$ study in six US cities. Am Rev Respir Dis 1987;136:1371-6.

14 Dockery DW, Speizer FE, Ferris BG Jr, Ware JH, Louis TA, Spiro A. Cumulative and reversible effects of lifetime smoking oncs simple tests of lung function in adults. Am Rev Respir Dis $\vec{O}$ 1988; 137:286-92.

15 SAS Institute Inc. SAS/STAT guide for personal computers. 6th ed. Cary, NC:SAS Institute Inc, 1985.

\section{Vancouver style}

All manuscripts submitted to the $\mathrm{Br} J$ Ind Med should conform to the uniform requirements for manuscripts submitted to biomedical journals (known as the Vancouver style)

The $\mathrm{Br} J$ Ind Med, together with many other international biomedical journals, has agreed to accept articles prepared in accordance with the Vancouver style. The style (described in full in Br Med J, 24 February 1979, p 532) is intended to standardise requirements for authors.

References should be numbered consecutively in the order in which they are first mentioned in the text by Arabic numerals above the line on each occasion the reference is cited (Manson ${ }^{1}$ confirmed other reports ${ }^{2-5} \ldots$.). In future references to papers submitted to the $\mathrm{Br} J$ Ind Med should include: the names of all authors if there are six or less or, if there are more, the first three followed by et al; the title of journal articles or book chapters; the titles of journals abbreviated according to the style of Index Medicus; and the first and final page numbers of the article or chapter.

Examples of common forms of references are:

I International Steering Committee of Medical Editors. Uniform requirements for manuscripts submitted to biomedical journals. Br Med J 1979;1:532-5.

2 Soter NA, Wasserman SI, Austen KF. Cold urticaria: release into the circulation of histamine and eosino-phil chemotactic factor of anaphylaxis during cold challenge. $N$ Engl J Med 1976;294:687-90.

3 Weinstein L, Swartz MN. Pathogenic properties of invading micro-organisms. In: Sodeman WA Jr, Sodeman WA, eds. Pathologic physiology: mechanisms of disease. Philadelphia: W B Saunders, 1974:457-72. 